\title{
Reduction of Cr (VI) by Micrococcus luteus isolate from Common Effluent Treatment Plants (CETPs)
}

\author{
P. Katyal* and G. Kaur \\ Department of Microbiology, Punjab Agricultural University, Ludhiana-141004, India \\ *Corresponding author
}

\section{A B S T R A C T}

The present study was envisaged with the objective to isolate indigenous chromate tolerant

Keywords

Bioremediation, CETPs, DPC, Cr (VI) reduction, $16 \mathrm{~S}$ rDNA sequencing

Article Info

Accepted:

06 June 2018

Available Online:

10 July 2018 bacteria from effluents and their subsequent utilization for chromium uptake or reduction. Samples were collected from two different Common Effluent Treatment Plants (CETPs), located in Ludhiana (sample 1) and Jalandhar (sample 2). In both the samples, chromium was found to be the dominant metal contaminant. A total of 10 morphologically distinct isolates were tested for their tolerance to chromium in terms of minimum inhibitory concentration (MIC) of $\mathrm{Cr}$ required for complete inhibition of growth. Four isolates (HM 2, HM 3, HM 15 and HM 16) showed maximum tolerance to chromium. There was no active uptake of $\mathrm{Cr}$ in sample 1 but considerable uptake was observed in sample 2 . Chromium reduction efficiency was determined by S-diphenyl-carbazide (DPC) method, whereby complete reduction was observed with the standard culture (Shewanella putrefaciens) followed by $76.66 \%$ by HM 16 and $46.76 \%$ by HM 2 after 7 hours of incubation. Molecular characterization of most potent isolate (HM 16) was carried out using $16 \mathrm{~S}$ rDNA based molecular method.

\section{Introduction}

Chromium is one of the most toxic heavy metal used in several industries and is a common industrial pollutant. A large quantity of chromium is discharged into the environment mainly from industrial operations including metal finishing industry, petroleum refinery, leather tanning, iron and steel industries and causes a serious threat to human health (Oladipo et al., 2014; Dixit et al., 2015). The effluents of these industries contain chromium at concentrations ranging from tenths to hundreds of milligrams per liter
(Dermou et al., 2005; Boyd 2010, Singh and Prasad 2015). Safe value in water for drinking purposes is $0.05 \mathrm{mg} / \mathrm{L}$ and recommended value for discharge is less than $5 \mathrm{mg} / \mathrm{L}$ (Directive EPA, USA, 2003; Debabrata et al., 2006).

In nature, chromium mainly exists in two forms, hexavalent $\mathrm{Cr}$ (VI) and trivalent $\mathrm{Cr}$ (III) form. In the industrial wastes it is primarily present in the hexavalent form as divalent oxyanions, chromate $\left(\mathrm{CrO}_{4}{ }^{2-}\right)$ and dichromate $\left(\mathrm{Cr}_{2} \mathrm{O}_{7}{ }^{2-}\right)$. It is an essential trace metal, but overexposure to $\mathrm{Cr}$ (VI) produces 
ulceration in the skin, mucous membranes and nasal septum, allergic dermatitis, renal tubular necrosis and increases risks of respiratory tract-cancer (Lu and Yang 1995; Flavio et al., 2004). The hexavalent chromium compounds are comparatively more toxic than those of $\mathrm{Cr}$ (III) due to their higher solubility in water, rapid permeability through biological membranes and subsequent interaction with intracellular proteins and nucleic acids (Basu et al., 1997). Hexavalent chromium (Cr (VI)) reduction to trivalent chromium (Cr (III)) could constitute a potential detoxification process that could be achieved via chemical or biological methods. However, chemical reduction requires energy input and large quantities of chemicals and generation of sludge (Srivastava et al., 1986; Hashim et al., 2011; Yao et al., 2012). Biological reduction could, therefore, provide a useful alternative economical process (Congeevaram et al., 2007). The processes by which microorganisms interact with toxic metals enabling their removal and recovery are bioaccumulation, biosorption and enzymatic reduction (Ohtake and Silver 1994; Srinath et al., 2002).

Reduction of Cr (VI) to $\mathrm{Cr}$ (III) represents a potentially useful approach for the detoxification of chromate from wastewater and environment (Marsh and McInerney, 2001; Liu et al., 2012; Shah et al., 2014). Biological $\mathrm{Cr}$ (VI) detoxification which is more ecofriendly and an economically feasible technology can be a suitable approach (Wang and Xiao 1995; Mclean and Beveridge 2001; Srinath et al., 2002; Elangovan et al., 2006). However, the potential for biological treatment of $\mathrm{Cr}$ (VI)-contaminated waste is limited because some microorganisms lose viability in the presence of high concentrations of chromate. Isolating chromate-reducing bacteria from contaminated environments could therefore be useful (Dmitrenko et al., 2003; Balamurugan et al., 2014, Katyal et al.,
2015). In Bacillus sp. ES29 chromate reducing activity was localized in the cell free extract which utilizes NADH as the sole electron donor (Pal et al., 2005). In some cases, the reduction of $\mathrm{Cr}$ (VI) was shown to take place in the extracellular domain due to the excretion of metabolites possessing a chemical reducing power. For example, Thiobacillus ferrooxidans was shown to generate sulphite and thiosulfate which reduce $\mathrm{Cr}$ (VI) at low $\mathrm{pH}$ (Sisti et al., 1996). The Cr (VI) reduction by bacterial cultures (Klaus-Joerger et al., 2001; Francisco et al., 2002; Cheung and $\mathrm{Gu}$ 2003; Ilias et al., 2011) has been extensively studied under aerobic and/or anaerobic conditions. This work mainly focuses on the isolation of chromium resistant strains of bacteria for the reduction/uptake of $\mathrm{Cr}$ (VI) and their applicability in treatment of metalrich effluents.

\section{Materials and Methods}

\section{Sample collection and preparation}

Effluent samples were collected from Punjab Small Industries and Export Cooperation (PSIEC) Leather Complex common effluent treatment plant (CETP), Kapoorthala road, Jalandhar and Ludhiana Electroplaters Association CETP, Focal Point, Ludhiana. Samples were collected in sterile plastic containers in the month of SeptemberOctober, 2015 and were allowed to settle for 2h. After filtration through Whatmann filter No. 1, samples were tested for their $\mathrm{pH}$, Chemical Oxygen Demand (COD), dissolved oxygen (DO), Biological Oxygen Demand (BOD) using standard methods (APHA 2001).

\section{Heavy metal profile of effluent}

The concentration of heavy metals present in both the effluent samples was estimated using Inductively Coupled Argon Plasma-Atomic Emission Spectroscopy (ICAP-AES). One 
hundred $\mathrm{ml}$ of sample was digested with $5 \mathrm{ml}$ of concentrated $\mathrm{HNO}_{3}$ and suitably diluted for heavy metal analysis by iCAP 6300 (Singh et al., 2015).

\section{Procurement and maintenance of standard culture}

The standard culture of Shewanella putrefaciens MTCC 8104 was procured from Institute of Microbial Technology (IMTECH), 39A, Sector 39, Chandigarh, India. It was maintained by periodic sub-culturing on Luria Bertani Agar after every 3 weeks.

\section{Isolation and maintenance of bacterial isolates}

Isolation of indigenous chromium resistant bacteria was carried out using standard microbiological techniques by which Luria Bertani Agar plates supplemented with $5 \mathrm{mg} / \mathrm{L}$ concentration of $\mathrm{Cr}$ was used. Pure cultures of bacterial colonies were preserved at $4^{\circ} \mathrm{C}$ as slant cultures for further analysis.

Determination of Minimum Inhibitory Concentration (MIC) of different selected heavy metals

Maximum resistance of the isolates to $\mathrm{Cr}$ was evaluated in LB agar plates amended with $\mathrm{Cr}$ in concentration ranging from $5 \mathrm{ppm}$ to 100ppm. The lowest concentration of heavy metal at which no growth occurred when compared with the control plates was considered as the Minimum Inhibitory Concentration (MIC).

\section{Determination of heavy metal uptake by selected isolates}

To determine the ability of selected isolates for heavy metal uptake, attempt was made to grow both the selected isolates on effluent samples collected from Ludhiana (sample 1) and Jalandhar (sample 2). Two-fifty $\mathrm{ml}$ of effluent sample was taken in $500 \mathrm{ml}$ volumetric flask, autoclaved at $15 \mathrm{lbs}$ for 20 minutes and was inoculated with $0.2 \mathrm{ml}$ of 12 hour old culture of HM 2 and HM 16 individually. Samples were taken to observe the heavy metal profile after 5 days and 10 days of growth. A set of un-inoculated effluent sample was kept as control. Following set of treatments were used:

Control:- Effluent samples as such without any modification was used as growth medium for both the selected isolates.

Treatment 1:- Effluent samples were supplemented with D-glucose-2.5 g/L, $\mathrm{MgSO}_{4} \cdot 7 \mathrm{H}_{2} \mathrm{O}-0.5 \mathrm{~g} / \mathrm{L}$ and $\mathrm{KNO}_{3}-0.18 \mathrm{~g} / \mathrm{L}$.

Treatment 2:- Effluent samples were modified to adjust their $\mathrm{pH}$ at 6.0 because at this $\mathrm{pH}$ most of the metals exists in their free ion state.

Treatment 3:- Effluent samples were supplemented as in Treatment 1 and their $\mathrm{pH}$ was adjusted to 6.0.

Growth profile of selected isolates w.r.t standard culture

Growth of selected isolates w.r.t standard culture was studied in $250 \mathrm{ml}$ flasks containing $50 \mathrm{ml}$ sterile LB broth. These flasks were inoculated separately with $0.5 \mathrm{ml}$ of overnight culture of selected isolates and standard culture and agitated on a rotary shaker at $150 \mathrm{rpm}$. Growth was monitored by measuring the optical density (O.D) at $600 \mathrm{~nm}$ using spectrophotometer at different time interval 0, 1, 2, 3, 4, 5, 6 and $7 \mathrm{~h}$ (Camargo et al., 2003).

\section{Chromium reduction efficiency of selected isolates and standard culture}

Selected isolates and the standard culture were grown in $50 \mathrm{ml}$ of LB medium with $20 \mathrm{ppm}$ $\mathrm{K}_{2} \mathrm{Cr}_{2} \mathrm{O}_{7}$ at $37^{\circ} \mathrm{C}$ with orbital shaking (150 
rpm). Samples were withdrawn at $1 \mathrm{~h}$ interval and centrifuged at 10,000 rpm for $5 \mathrm{~min}$ and the supernatants were assayed for residual $\mathrm{Cr}$ (VI) concentration by using Sdiphenylcarbazide (DPC) method (Barlett and James 1996). Hexavalent chromium was determined colorimetrically. Standard curve was plotted with the different readings obtained by taking absorbance at $540 \mathrm{~nm}$.

\section{Determination of site of chromate reductase activity}

The reaction for the chromate reductase activity contained $20 \mathrm{mg} / \mathrm{L} \mathrm{Cr}(\mathrm{VI})$ as $\mathrm{K}_{2} \mathrm{Cr}_{2} \mathrm{O}_{7}$ in $0.5 \mathrm{ml}$ of $100 \mathrm{mM}$ phosphate buffer, held at $37^{\circ} \mathrm{C}$ in a water bath. Bacteria were grown overnight in $100 \mathrm{ml}$ of LB medium with 20 $\mathrm{mg} / \mathrm{L} \mathrm{K}_{2} \mathrm{Cr}_{2} \mathrm{O}_{7}$ at $37^{\circ} \mathrm{C}$ with orbital shaking (150rpm). Thereafter, cells of each isolate were harvested by centrifugation of $30 \mathrm{ml}$ culture at $5,000 \mathrm{rpm}$ for $10 \mathrm{~min}$. Culture supernatant was collected and the cell pellet was resuspended in $30 \mathrm{ml}$ phosphate buffer (10 mM, pH 7). Cells in an ice bath were disrupted with an ultrasonic probe. Power was applied ten times in 30s pulses with 30s intervals. The sonicate was centrifuged at $16,000 \mathrm{rpm}$ at $4^{\circ} \mathrm{C}$ for $20 \mathrm{~min}$. Cell extract supernatant was transferred in a fresh tube and was kept in ice. Cell lysate was also resuspended in $30 \mathrm{ml}$ phosphate buffer (Ilias et al., 2011).

The reaction was initiated by the addition of $0.5 \mathrm{ml}$ each of culture supernatant, cell extract supernatant and cell lysate and residual $\mathrm{Cr}$ (VI) concentration was measured after $1 \mathrm{~h}$ following the (DPC) method. One unit of enzyme activity was defined as $1 \mu \mathrm{mol}$ of $\mathrm{Cr}$ (VI) reduced $/ \mathrm{min} / \mathrm{ml}$ at $37^{\circ} \mathrm{C}$.

\section{Molecular identification of the bacterial isolate by $16 \mathrm{~S}$ rDNA sequencing}

Molecular identification of the bacterial isolate was done through outsourcing by
Eurofins Genomics India Pvt Ltd. DNA was isolated and its quality was evaluated on $1.0 \%$ Agarose Gel, a single band of high-molecular weight DNA has been observed. Fragment of $16 \mathrm{~S}$ rDNA gene was amplified by $27 \mathrm{~F}$ and 1492R primers. A single discrete PCR amplicon band of $1500 \mathrm{bp}$ was observed when resolved on Agarose gel. Forward and reverse DNA sequencing reaction of PCR amplicon was carried out with forward primer and reverse primers using BDT v3.1 Cycle sequencing kit on ABI 3730xl Genetic Analyzer. Consensus sequence of $16 \mathrm{~S}$ rDNA gene was generated from forward and reverse sequence data using aligner software. The $16 \mathrm{~S}$ rDNA gene sequence was used to carry out BLAST with the database of NCBI genbank database. Based on maximum identity score first ten sequences were selected and aligned using multiple alignment software program Clustal W. Distance matrix was generated and the phylogenetic tree was constructed using MEGA 7 (Kumar et al., 2016).

\section{Results and Discussion}

\section{Physico-chemical and Comparative heavy metal profile of effluents from CETPs}

Effluent sample taken from Ludhiana (sample 1) was found to be highly acidic ( $\mathrm{pH}-2.5)$ with BOD of $17.2 \mathrm{mg} / \mathrm{l}$ and COD about $390 \mathrm{mg} / \mathrm{l}$. Whereas, sample 2 (tannery effluent from Jalandhar) was showing $\mathrm{pH}-9.0$ with BOD value $69.8 \mathrm{mg} / \mathrm{l}$ and COD of $372 \mathrm{mg} / \mathrm{l}$, indicating far difference in physico-chemical parameters of effluents depending on type of industries these are catering for. Sample 1 was taken from a CETP mainly receiving waste from electroplating industries of Ludhiana and sample 2 was from a CETP handling tannery waste. Dissolved oxygen content of sample 1 was $47.8 \pm 0.5$ and of sample 2 was $90.3 \pm 0.3$. The heavy metal profile of both the effluent samples was determined by using Inductively Coupled Argon Plasma-Emission Spectroscopy (ICAP) analysis by the method 
of Thompson and Walsh (1989). Both the samples were pretreated as suggested by Singh et al., (2015). Sample 1 was analyzed for complete metal profile irrespective of the fact that these metals are of environmental concern or not, whereas, for sample 2 only the heavy metal contaminants of environmental concern was recorded and others are mentioned as N.D (not-determined). The results presented in Table 1 revealed that in sample $1, \mathrm{Cr}$ was found to be the dominant metal contaminant with a concentration of $238 \mathrm{ppm}$, followed by nickel (92 ppm), copper (18.9 ppm), lead (18.5 ppm) and cadmium (0.3 ppm). In sample 2 also, highest level of $\mathrm{Cr}$ (23.2 ppm) followed by lead (20.6 ppm), $\mathrm{Ni}(6.65 \mathrm{ppm})$ and $\mathrm{Cd}$ (0.32 ppm) was observed.

The level of heavy metal contaminants in sample 1 was higher in comparison to sample 2 and was above permissible limits in both the samples. The concentration of $\mathrm{Cr}$ was 2380 times higher than the permissible limit in sample 1. This is in accordance with the earlier study by Verma et al., (2001), who analyzed tannery effluents for the content of the various heavy metals and found that the total chromium (28.96 ppm) and nickel concentrations $(1.08 \mathrm{ppm})$ in the effluent exceeds the permissible limits.

\section{Isolation of heavy metal resistant bacteria}

For isolation of chromate tolerant bacteria, the samples were enriched in peptone water and incubated for 18 hours at $37^{\circ} \mathrm{C}$. Then the loopful of sample was streaked as such on Luria Bertani (LB) agar plates amended with $\mathrm{K}_{2} \mathrm{Cr}_{2} \mathrm{O}_{7}$ at concentration of $5 \mathrm{ppm}$. The plates were incubated at $37{ }^{\circ} \mathrm{C}$ for $24-48$ hour. Different bacterial isolates were obtained by picking well isolated colony and transferring on LB slant. A total of 21 bacterial isolates were isolated and purified. These isolates were named as HM 1 to HM 21. Similarly, Pandit et al., (2013) isolated 40 isolates from industrial effluent samples which can tolerate $50 \mathrm{ppm}$ of different metal i.e $\mathrm{Cu}, \mathrm{Cd}, \mathrm{Ni}$ and $\mathrm{Cr}$ concentrations. Singh et al., (2013) isolated fifty three morphologically different bacterial strains from the treated tannery effluent and eighteen strains were selected for the determination of chromate reduction efficiency on the basis of higher MIC values. Five morphologically different $\mathrm{Cr}$ (VI) resistant bacterial strains designated as TUVK1, TUV-K2, TUV-K3, TUV-K4 and TUVK5 were isolated from the treated tannery effluent (Vijayananda and Hemapriya 2014).

\section{Determination of Minimum Inhibitory Concentration (MIC) of different selected heavy metals}

Minimum Inhibitory Concentration (MIC) was determined by growing cells in LB agar plates amended with different concentrations of $\mathrm{Cr}$ in the form of their salt $\mathrm{K}_{2} \mathrm{Cr}_{2} \mathrm{O}_{7}$. The isolates were grown on increasing concentration (5$120 \mathrm{ppm}$ ) of $\mathrm{Cr}$ till there is complete inhibition of growth (Table 2). Four isolates i.e HM 2, HM 3, HM 15 and HM 16 showed maximum tolerance (upto $120 \mathrm{ppm}$ ) to $\mathrm{Cr}$. In another study, isolation of 53 different species was carried out from the sediment samples collected from Krishna Godavari basin. Of these isolates, $79.24 \%$ were found to be resistant to $350 \mathrm{ppm}$ of Mercury (11.53\%), $250 \mathrm{ppm}$ of Cadmium (3.77\%), 700ppm of Chromate $(50.94 \%)$ and $250 \mathrm{ppm}$ of Zinc (13.20\%) (Gunaseelan and Ruban, 2011).

In the study carried out by Alam et al., (2011), a total of 198 bacteria were isolated, 88 from the tannery effluents and 110 from agricultural soil irrigated with the tannery effluents. All isolates were tested for resistance against $\mathrm{Cr}^{6+}$, $\mathrm{Cr}^{3+}, \mathrm{Ni}^{2+}, \mathrm{Zn}^{2+}, \mathrm{Cu}^{2+}, \mathrm{Cd}^{2+}$ and $\mathrm{Hg}^{2+}$. Maximum bacterial isolates were found to be resistant to $\mathrm{Cr}^{6+} 178$ (89.9\%) followed by $\mathrm{Cr}^{3+}$ 146 (73.7\%), $\quad \mathrm{Cd}^{2+} 86 \quad(43.4 \%), \quad \mathrm{Zn}^{2+} 83$ (41.9\%), $\mathrm{Ni}^{2+} 61 \quad(30.8 \%)$ and $\mathrm{Cu}^{2+} 51$ 
(25.6\%). However, most of the isolates were sensitive to $\mathrm{Hg}^{2+}$. Among the isolates from tannery effluents, $97.8 \%$ were resistant to $\mathrm{Cr}^{6+}$ and $64.8 \%$ were resistant to $\mathrm{Cr}^{3+}$.

\section{Determination of $\mathrm{Cr}$ uptake by selected isolates}

The concentration of $\mathrm{Cr}$ in effluent samples was determined by using Inductively Coupled Argon Plasma-Atomic Emission Spectroscopy (ICAP-AES) analysis. Attempt was made to grow both the selected bacterial isolates on the effluent samples and $\mathrm{Cr}$ uptake by the isolates was determined by measuring the $\mathrm{Cr}$ concentration in the inoculated effluents after 5 days and 10 days of growth. Samples were analyzed for any decrease in $\mathrm{Cr}$ concentration by ICAP-AES.

\section{Determination of heavy metal uptake in effluent sample 1 (Ludhiana-CETP)}

To determine the $\mathrm{Cr}$ uptake, Four set of treatments were used, and $\mathrm{Cr}$ uptake in effluent sample as such (Control), effluent sample with supplements (Treatment 1), Effluent sample with $\mathrm{pH}$ adjustment (Treatment 2), Effluent sample both with supplements and $\mathrm{pH}$ adjustment (Treatment 3) was determined.

Control: Untreated effluent sample 1 was inoculated with the selected isolates i.e. HM 2 (U 2) and HM 16 (U 10) and was observed for microbial growth in terms of increase in optical density w.r.t un-inoculated control $\mathrm{U}(\mathrm{C})$. The heavy metal profile was recorded after 5 and 10 days of growth and compared with un-inoculated control $\mathrm{U}(\mathrm{C})$ by using ICAP-AES. The results revealed that there was no decrease in concentration of $\mathrm{Cr}$ even after 5 and 10 days of incubation (Table 3) indicating that none of the isolate is showing any metal uptake. Though an increase in concentration of metal can be linked to increase availability of metal in soluble form due to acid production accompanied with microbial growth.

Treatment 1: Sample was supplemented with D-glucose-2.5 g/L, $\mathrm{MgSO}_{4} .7 \mathrm{H}_{2} \mathrm{O}-0.5 \mathrm{~g} / \mathrm{L}$ and $\mathrm{KNO}_{3}-0.18 \mathrm{~g} / \mathrm{L}$ and inoculated with selected isolates. Supplemented effluent sample 1 was inoculated with the selected isolates i.e. HM 2 (S 2) and HM 16 (S 16) and was observed for microbial growth in terms of increase in optical density w.r.t un-inoculated control $\mathrm{S}(\mathrm{C})$. The heavy metal profile was measured after 5 and 10 days of growth and compared with un-inoculated control $\mathrm{S}(\mathrm{C})$ by using ICAP-AES. Table 4 revealed that even after supplementation there was no uptake of heavy metals by selected isolates.

Treatment 2: The $\mathrm{pH}$ of the sample was altered to 6 and inoculated with selected isolates. The concentration of $\mathrm{Cr}$ was measured after 5 and 10 days by ICAP-AES analysis. The initial concentration in the control was decreased due to precipitation of metal ions whereas no uptake was observed in the inoculated samples (Table 5). From these results, it is clearly shown that the $\mathrm{pH}$ in the range between 5.5 and 6 is nearly the same range of $\mathrm{pH}$ at which the different metals under investigation exist in free ion state.

Treatment 3: Sample was supplemented as well as the $\mathrm{pH}$ of the sample was altered and inoculated with the selected isolates. The concentration of $\mathrm{Cr}$ was measured after 5 and 10 days by using ICAP-AES analysis. The results revealed the decrease in concentration in the control due to precipitation of metal ions.

The results of the above four treatments indicated that there was no active uptake of $\mathrm{Cr}$ (VI) by any of the selected isolates even after 5 and 10 days of growth in sample 1. Active uptake was not observed even after adjustment 
of $\mathrm{pH}$ and incorporation of supplements, individually as well as collectively (Table 5 and 6). An increase in metal concentration, after 5 and 10 days of growth, might be correlated to increased acidity of the sample due to acid production from the microbes. Both the isolates were growing in effluent sample at a very low rate with increase in O.D of HM 2 (0.01 to 0.052) and HM 16 (0.03 to 0.062). This indicated that the strains were unable to bioaccumulate heavy metals in initial 5-10 days of active growth in effluent sample 1 containing a very high level of heavy metal contaminants. The concentration of heavy metals was higher than the MIC of selected isolates.

\section{Determination of heavy metal concentration in effluent sample 2 (Jalandhar-CETP)}

To determine the $\mathrm{Cr}$ uptake, two treatments were used, $\mathrm{Cr}$ uptake in effluent sample with $\mathrm{pH}$ adjustment to 6 (Treatment 1) and effluent sample with supplements and $\mathrm{pH}$ adjustment (Treatment 2) was determined.

Treatment 1: The $\mathrm{pH}$ of the sample was altered to 6 and samples were inoculated with selected isolates. The concentration of $\mathrm{Cr}$ was measured after 5 and 10 days of growth by ICAP-AES analysis. The result indicated a significant decrease in concentration of $\mathrm{Cr}$ (VI) by the selected isolates (Table 7).

Treatment 2: The sample was supplemented with D-glucose- $2.5 \mathrm{~g} / \mathrm{L}, \mathrm{MgSO}_{4} .7 \mathrm{H}_{2} \mathrm{O}-0.5 \mathrm{~g} / \mathrm{L}$ and $\mathrm{KNO}_{3}-0.18 \mathrm{~g} / \mathrm{L}$ as well as the $\mathrm{pH}$ of the sample was altered. The concentration was measured after 5 and 10 days by ICAP-AES analysis. From the results, a significant decrease in concentration of $\mathrm{Cr}$ was observed even after 5 days of incubation (Table 8).

As indicated in above tables sample 2 (JCETP) supported good growth of microbes indicating the lower level of heavy metal contaminants. Active growth of isolates corelate well with their heavy metal uptake revealed $(99 \%)$ reduction of $\mathrm{Cr}$ in sample $2(\mathrm{~J}-$ CETP).

Growth profile of selected isolates w.r.t standard culture in $\mathrm{Cr}$ (VI) supplemented media

As revealed in Tables (3-6), both the selected isolates were unable to show any $\mathrm{Cr}$ uptake in effluent sample 1, even after supplementation with D-glucose, $\mathrm{MgSO}_{4}$ and $\mathrm{KNO}_{3}$ and $\mathrm{pH}$ adjustment to 6.0. Whereas, both the isolates were showing comparatively higher growth and active $\mathrm{Cr}$ uptake in effluent sample 2 (Table 7 and 8). To further determine the ability of selected isolates to show reduction of $\mathrm{Cr}$ (VI) to $\mathrm{Cr}$ (III), both the isolates were tested for enzyme chromate reductase and compared with a standard strain Shewanella putrefaciens (MTCC 8104).

The growth profile of selected isolates with respect to standard culture (Shewanella putrefaciens) was determined in $\mathrm{Cr}$ (VI) supplemented media (Figure 1). Both the isolates (HM-2 and HM-16) and Shewanella putrefaciens (S) were inoculated in a media supplemented with $20 \mathrm{ppm}$ of $\mathrm{Cr}$ (VI) and incubated on incubator shaker at $37^{\circ} \mathrm{C}$ temp and $100 \mathrm{rpm}$. Samples were withdrawn at $1 \mathrm{~h}$ interval and absorbance was measured at 540 $\mathrm{nm}$. The maximum growth was shown by the standard culture $(0.021$ to 1.245$)$ followed by the growth of HM 16 and HM 2 after $7 \mathrm{~h}$ of incubation (Table 9). Similarly, Singh et al., (2013) measured the growth of chromate tolerant bacterial isolate (Bacillus cereus) in anaerobic broth in the presence or absence of $\mathrm{Cr}$ (VI) at different concentrations of $\mathrm{Cr}$ (VI). The results revealed that the rate of growth of $B$. cereus decreased with the increase in $\mathrm{Cr}$ (VI) concentration of the medium and the chromate reduction was directly correlated to the growth of the strain. 
Chromium reduction efficiency of selected isolates and standard culture

The chromium reduction efficiency of selected isolates and standard culture was determined by S-diphenylcarbazide (DPC) method as discussed above. The results revealed complete reduction of $\mathrm{Cr}$ (VI) by the standard culture followed by $76.66 \%$ reduction by HM 16 and $46.76 \%$ reduction by HM 2 after 7 hours of incubation (Table 10, Figure 2). Camargo et al., (2003) isolated some chromium resistant bacteria that can tolerate or reduce $\mathrm{Cr}(\mathrm{VI})$ at concentrations of 1500-
$2500 \mathrm{mg} / \mathrm{L}$. It has been reported that Bacillus sp. ES29 reduced 90\% of Cr (VI) added @ $2 \mathrm{mg} / \mathrm{L}$ to the medium in less than $6 \mathrm{~h}$. Similarly, Ilias et al., (2011) isolated two chromium resistant bacteria (IFR-2 and IFR-3) capable of reducing/transforming $\mathrm{Cr}(\mathrm{VI})$ to $\mathrm{Cr}$ (III) from tannery effluents. Thacker and Madamwar (2005) have shown that the bacterial isolate DM1 reduces $50 \mathrm{ppm}$ of chromium to $0 \mathrm{ppm}$ in $54 \mathrm{~h}$. They added a second aliquot of chromium which was reduced to $0 \mathrm{ppm}$ in $99 \mathrm{~h}$, and the third aliquot was reduced to $21.8 \mathrm{ppm}$ in 126 hour.

Table.1 Comparative heavy metal profile of effluents from CETPs

\begin{tabular}{|l|l|c|c|c|}
\hline S.No & Metals & Sample no. 1 & Sample no. 2 & Permissible limit \\
\hline 1. & Cadmium $(\mathrm{Cd})$ & 0.30 & 0.32 & \\
\hline $\mathbf{2 .}$ & Chromium $(\mathbf{C r})$ & $\mathbf{2 3 8 . 0}$ & $\mathbf{2 3 . 2}$ & $\mathbf{0 . 1 0}$ \\
\hline $\mathbf{3 .}$ & Copper $(\mathrm{Cu})$ & 18.9 & 0.0075 & 3.00 \\
\hline $\mathbf{4 .}$ & Iron $(\mathrm{Fe})$ & 5840 & 0.023 & 3.00 \\
\hline $\mathbf{5 .}$ & Magnesium $(\mathrm{Mg})$ & 45 & N.D & N.D \\
\hline 6. & Nickel $(\mathrm{Ni})$ & 92 & 6.65 & 3.00 \\
\hline 7. & Lead $(\mathrm{Pb})$ & 18.5 & 20.6 & 0.1 \\
\hline $\mathbf{8 .}$ & Zinc $(\mathrm{Zn})$ & 266 & 0.0063 & 5.0 \\
\hline
\end{tabular}

N.D - Not determined

Table.2 Minimum inhibitory concentration (MIC) of morphologically distinct isolates

\begin{tabular}{|c|c|}
\hline Isolate No. & $\mathrm{Cr}$ \\
\hline & concentration in ppm \\
\hline HM 1 & 30 \\
\hline HM 2 & $\mathbf{1 2 0}$ \\
\hline HM 3 & $\mathbf{1 0 0}$ \\
\hline HM 5 & 10 \\
\hline HM 8 & 30 \\
\hline HM 9 & 20 \\
\hline HM 12 & 70 \\
\hline HM 14 & 30 \\
\hline HM 15 & $\mathbf{1 1 0}$ \\
\hline HM 16 & $\mathbf{1 0 0}$ \\
\hline
\end{tabular}


Table.3 Heavy metal concentration in untreated effluent sample (1) determined by using ICAP-AES

\begin{tabular}{|c|c|c|c|c|c|c|}
\hline & \multicolumn{2}{|c|}{ Sample } & \multicolumn{3}{c|}{ (after 5 days) } & \multicolumn{3}{c|}{ (after 10 days) } \\
\hline Metals & $\mathbf{U}(\mathbf{C})$ & $\mathbf{U} \mathbf{2}$ & $\mathbf{U} \mathbf{1 6}$ & $\mathbf{U}(\mathbf{C})$ & $\mathbf{U} \mathbf{2}$ & $\mathbf{U} \mathbf{1 6}$ \\
\hline & & & Concentration in ppm & & $\mathbf{3 1 4}$ \\
\hline $\mathbf{C r}$ & $\mathbf{2 3 8}$ & $\mathbf{3 4 1}$ & $\mathbf{2 9 8}$ & $\mathbf{2 8 3}$ & $\mathbf{3 3 5}$ & $\mathbf{3 1}$ \\
\hline $\mathbf{C u}$ & 18.9 & 29.5 & 25.5 & 24.4 & 28.6 & 27.1 \\
\hline $\mathbf{F e}$ & 5840 & 6940 & 6975 & 6650 & 6560 & 6930 \\
\hline $\mathbf{M n}$ & 46.4 & 55.8 & 59.2 & 56.6 & 57.1 & 61.9 \\
\hline $\mathbf{N i}$ & 92 & 102 & 106 & 119 & 137 & 133 \\
\hline $\mathbf{P b}$ & 18.5 & 24.9 & 25.7 & 22.3 & 25.2 & 27.1 \\
\hline $\mathbf{Z n}$ & 266 & 310 & 301 & 293 & 309 & 309 \\
\hline $\mathbf{C d}$ & 0.30 & 0.49 & 0.41 & 0.39 & 0.45 & 0.43 \\
\hline
\end{tabular}

U indicating - Untreated effluent sample

Table.4 Heavy metal concentration in supplemented effluent sample (1) determined by using ICAP-AES

\begin{tabular}{|c|c|c|c|c|c|c|}
\hline & \multicolumn{2}{|c|}{ Samples } & \multicolumn{3}{c|}{ (after 5 days) } & \multicolumn{3}{c|}{ (after 10 days) } \\
\hline Heavy Metals & S(C) & $\mathbf{S ~ 2}$ & $\mathbf{S ~ 1 6}$ & $\mathbf{S}(\mathbf{C})$ & $\mathbf{S ~ 2}$ & $\mathbf{S ~ 1 6}$ \\
\hline & & \multicolumn{5}{c|}{ Concentration in ppm } \\
\hline Cr & $\mathbf{3 3 2}$ & $\mathbf{3 3 6}$ & $\mathbf{2 9 1}$ & $\mathbf{2 7 0}$ & $\mathbf{2 9 0}$ & $\mathbf{2 9 3}$ \\
\hline $\mathbf{C u}$ & 28.7 & 29 & 25.5 & 23.5 & 24.9 & 25 \\
\hline $\mathbf{F e}$ & 7415 & 7780 & 6345 & 6490 & 6830 & 6920 \\
\hline $\mathbf{M n}$ & 65.8 & 66.9 & 60.1 & 54.1 & 57 & 57.7 \\
\hline $\mathbf{N i}$ & 138 & 137 & 125 & 117 & 121 & 124 \\
\hline $\mathbf{P b}$ & 28.1 & 27.4 & 27.5 & 20.7 & 24.5 & 27.2 \\
\hline $\mathbf{Z n}$ & 308 & 306 & 300 & 291 & 292 & 299 \\
\hline $\mathbf{C d}$ & 0.45 & 0.46 & 0.40 & 0.38 & 0.39 & 0.40 \\
\hline
\end{tabular}

$\mathrm{S}$ indicating - Supplemented effluent sample

Table.5 Heavy metal concentration in sample (1) with altered $\mathrm{pH}$ determined by using ICAP-AES

\begin{tabular}{|c|c|c|c|c|c|c|c|}
\hline & \multicolumn{2}{|c|}{ Samples } & \multicolumn{2}{c|}{ (after 5 days) } & \multicolumn{3}{c|}{ (after 10 days) } \\
\hline Heavy Metals & $\mathbf{P}(\mathbf{C})$ & $\mathbf{P ~ 2}$ & $\mathbf{P ~ 1 6}$ & $\mathbf{P}(\mathbf{C})$ & $\mathbf{P ~ 2}$ & P 16 \\
\hline & & \multicolumn{5}{|c|}{ Concentration in ppm } \\
\hline $\mathbf{C r}$ & $\mathbf{4 . 4}$ & $\mathbf{1 4}$ & $\mathbf{1 3}$ & $\mathbf{1 3}$ & $\mathbf{4 . 8}$ & $\mathbf{3 2}$ \\
\hline $\mathbf{C u}$ & 14.7 & 18.9 & 13 & 13.2 & 26.9 & 14.5 \\
\hline $\mathbf{F e}$ & 5405 & 3319 & 4508 & 4547 & 3373 & 4720 \\
\hline $\mathbf{M n}$ & 53.6 & 53.3 & 46.5 & 45.9 & 49.4 & 51.4 \\
\hline $\mathbf{N i}$ & 96 & 62 & 87 & 86 & 74 & 97 \\
\hline $\mathbf{P b}$ & 3.1 & 1.7 & 6 & 4.9 & 1.1 & 1.3 \\
\hline $\mathbf{Z n}$ & 2440 & 154 & 237 & 230 & 183 & 29 \\
\hline $\mathbf{C d}$ & 0.25 & 0.14 & 0.20 & 0.21 & 0.16 & 0.21 \\
\hline
\end{tabular}

$\mathrm{P}$ indicating - Altered $\mathrm{pH}$ 
Table.6 Heavy metal concentration in supplemented effluent sample (1) with altered pH determined by using ICAP-AES

\begin{tabular}{|c|c|c|c|c|c|c|c|}
\hline & \multicolumn{2}{|c|}{ Samples } & \multicolumn{3}{c|}{ (after 5 days) } & \multicolumn{3}{c|}{ (after 10 days) } \\
\hline Heavy Metals & SP(C) & SP 2 & SP 16 & SP(C) & SP 2 & SP 16 \\
\hline & \multicolumn{5}{|c|}{ Concentration in ppm } \\
\hline Cr & $\mathbf{2 . 9}$ & $\mathbf{1 8}$ & $\mathbf{1 6}$ & $\mathbf{3 . 8}$ & $\mathbf{1 6}$ & $\mathbf{3 4}$ \\
\hline $\mathbf{C u}$ & 9.6 & 9.4 & 15.8 & 14.3 & 23.3 & 18 \\
\hline $\mathbf{F e}$ & 5295 & 5305 & 4307 & 4616 & 3029 & 4460 \\
\hline $\mathbf{M n}$ & 57.3 & 66.6 & 46.2 & 50.5 & 56.5 & 51.7 \\
\hline $\mathbf{N i}$ & 56 & 51 & 78 & 66 & 74 & 92 \\
\hline $\mathbf{P b}$ & 1.3 & 1.9 & 4.1 & 0.5 & 2 & 3.5 \\
\hline $\mathbf{Z n}$ & 162 & 139 & 235 & 195 & 178 & 247 \\
\hline $\mathbf{C d}$ & 0.24 & 0.25 & 0.19 & 0.21 & 0.13 & 0.20 \\
\hline
\end{tabular}

SP indicating - Supplemented effluent sample with altered $\mathrm{pH}$

Table.7 Heavy metal concentration in sample (2) with altered $\mathrm{pH}$ determined by using ICAP-AES

\begin{tabular}{|c|c|c|c|c|c|c|}
\hline & Samples & \multicolumn{2}{|c|}{ (after 5 days) } & \multicolumn{2}{c|}{ (after 10 days) } \\
\hline Heavy Metals & Control & $\mathbf{P ~ 2}$ & P 16 & P 2 & P 16 \\
\hline & & \multicolumn{3}{|c|}{ Concentration in ppm } \\
\hline Cd & 0.0323 & 0.00125 & 0.0002 & 0.0018 & 0.0002 \\
\hline Cr & $\mathbf{2 3 . 2 0 5}$ & $\mathbf{0 . 5 5 0 9 5}$ & $\mathbf{0 . 0 0 1 4}$ & $\mathbf{0 . 6 0 6 9}$ & $\mathbf{0 . 0 0 3 4}$ \\
\hline $\mathbf{N i}$ & 6.6545 & 2.178 & 0.0153 & 1.9955 & 0.01825 \\
\hline $\mathbf{Z n}$ & 30.525 & 4.626 & 0.01925 & 4.3285 & 0.03095 \\
\hline $\mathbf{C u}$ & 1.907 & 0.8234 & 0.0173 & 0.6117 & 0.0191 \\
\hline $\mathbf{F e}$ & N.D & 31.07 & 0.021 & 26.96 & 0.0349 \\
\hline $\mathbf{M n}$ & 3.033 & 1.734 & 0.0948 & 1.713 & 0.116 \\
\hline $\mathbf{P b}$ & 20.61 & 1.231 & 0.0062 & 0.5985 & 0.0116 \\
\hline
\end{tabular}

$\mathrm{P}$ indicating - Altered $\mathrm{pH}$

Table.8 Heavy metal concentration in supplemented effluent sample (2) with altered $\mathrm{pH}$ determined by using ICAP-AES

\begin{tabular}{|c|c|c|c|c|c|}
\hline \multirow[b]{2}{*}{ Heavy Metal } & \multirow{2}{*}{$\begin{array}{l}\text { Samples } \\
\text { Control }\end{array}$} & \multicolumn{2}{|c|}{ (after 5 days) } & \multicolumn{2}{|c|}{ (after 10 days) } \\
\hline & & SP 2 & SP 16 & SP 2 & SP 16 \\
\hline & \multicolumn{5}{|c|}{ Concentration in ppm } \\
\hline Cd & 0.0323 & 0.00035 & 0.00025 & 0.00025 & 0.00025 \\
\hline $\mathrm{Cr}$ & 23.205 & 0.03365 & 0.00435 & 0.0082 & 0.0051 \\
\hline $\mathrm{Ni}$ & 6.6545 & 1.352 & 0.0341 & 0.7155 & 0.0722 \\
\hline Zn & 30.525 & 1.2365 & 0.0319 & 2.969 & 0.0662 \\
\hline $\mathrm{Cu}$ & 1.907 & 0.0252 & 0.0235 & 0.0486 & 0.0203 \\
\hline $\mathbf{F e}$ & N.D & -0.0024 & 0.0781 & 0.034 & 0.0347 \\
\hline Mn & 3.033 & 1.239 & 0.1263 & 1.916 & 0.1563 \\
\hline $\mathbf{P b}$ & 20.61 & 0.0081 & -0.0197 & 0.016 & 0.0083 \\
\hline
\end{tabular}

SP indicating - Supplemented effluent sample with altered $\mathrm{pH}$ 
Table.9 Time course of growth of selected isolates and standard culture

\begin{tabular}{|c|c|c|c|}
\hline & \multicolumn{3}{|c|}{ Isolates } \\
\hline Time & HM 2 & HM 16 & S.D at 540 nm \\
\hline 0 hour & & 0.012 & 0.021 \\
\hline $\mathbf{1}$ hour & 0.026 & 0.087 & 0.082 \\
\hline $\mathbf{2}$ hour & 0.043 & 0.135 & 0.132 \\
\hline $\mathbf{3}$ hour & 0.044 & 0.256 & 0.396 \\
\hline $\mathbf{4}$ hour & 0.096 & 0.421 & 0.859 \\
\hline $\mathbf{5}$ hour & 0.196 & 0.562 & 1.026 \\
\hline $\mathbf{6}$ hour & 0.382 & 0.643 & 1.184 \\
\hline $\mathbf{7}$ hour & 0.434 & 0.720 & 1.245 \\
\hline
\end{tabular}

Table.10 Chromium reduction efficiency of selected isolates and standard culture

\begin{tabular}{|c|c|c|c|c|c|c|}
\hline \multicolumn{7}{|c|}{ O.D at 540 nm } \\
\hline Time (h) & HM 2 & $\begin{array}{c}\text { \% } \\
\text { reduction }\end{array}$ & HM 16 & $\begin{array}{c}\text { \% } \\
\text { reduction }\end{array}$ & S & $\begin{array}{c}\text { \% } \\
\text { reduction }\end{array}$ \\
\hline $\mathbf{0}$ & 0.402 & & 0.453 & & 0.345 & \\
\hline $\mathbf{1}$ & 0.395 & 1.74 & 0.425 & 6.18 & 0.310 & 10.14 \\
\hline $\mathbf{2}$ & 0.391 & 2.73 & 0.324 & 28.47 & 0.246 & 28.69 \\
\hline $\mathbf{3}$ & 0.327 & 18.65 & 0.216 & 52.31 & -0.004 & 101.1 \\
\hline $\mathbf{4}$ & 0.290 & 27.86 & 0.174 & 61.58 & -0.036 & \\
\hline $\mathbf{5}$ & 0.234 & 41.79 & 0.121 & 73.28 & -0.300 & \\
\hline $\mathbf{6}$ & 0.228 & 43.28 & 0.118 & 73.95 & -0.196 & \\
\hline $\mathbf{7}$ & 0.214 & 46.76 & 0.106 & 76.66 & -1.034 & \\
\hline
\end{tabular}

Table.11 Determination of chromate reduction activity in different fractions

\begin{tabular}{|c|c|c|c|}
\hline Fraction & HM 2 & HM 16 & S \\
\hline \multicolumn{3}{|c|}{ Enzyme units $\boldsymbol{\mu m o l e ~ o f ~} \mathbf{C r}(\mathbf{V I})$ reduced/min/ml } \\
\hline Culture supernatant & 0.152 & 0.145 & 0.150 \\
\hline Cell extract supernatant & 0.161 & 0.163 & 0.175 \\
\hline Cell lysate & 0.141 & 0.135 & 0.137 \\
\hline
\end{tabular}


Table.12 Sequence producing significant alignments

\begin{tabular}{|l|c|c|c|c|c|c|}
\hline \multicolumn{1}{|c|}{ Description } & $\begin{array}{l}\text { Max } \\
\text { score }\end{array}$ & $\begin{array}{l}\text { Total } \\
\text { score }\end{array}$ & $\begin{array}{l}\text { Query } \\
\text { cover }\end{array}$ & E value & Ident & Accession \\
\hline $\begin{array}{l}\text { Micrococcus luteus strain } \\
\text { INBI-1 16S ribosomal RNA } \\
\text { gene, partial sequence }\end{array}$ & 2713 & 2713 & $100 \%$ & 0 & $99 \%$ & EU438932.1 \\
$\begin{array}{l}\text { Micrococcus luteus 16S rRNA } \\
\text { gene, isolate CV44 }\end{array}$ & 2710 & 2710 & $100 \%$ & 0 & $99 \%$ & AJ717369.1 \\
\hline $\begin{array}{l}\text { Micrococcus luteus partial } \\
\text { 16S rRNA gene, isolate B9 }\end{array}$ & 2708 & 2708 & $100 \%$ & 0 & $99 \%$ & $\begin{array}{l}\text { HG941665. } \\
\text { Micrococcus yunnanensis }\end{array}$ \\
$\begin{array}{l}\text { strain N1-7 16S ribosomal } \\
\text { RNA gene, partial sequence }\end{array}$ & 2708 & 2708 & $100 \%$ & 0 & $99 \%$ & JX094178.1 \\
\hline $\begin{array}{l}\text { Micrococcus sp. MN7-5 16S } \\
\text { ribosomal RNA gene, partial } \\
\text { sequence }\end{array}$ & 2708 & 2708 & $100 \%$ & 0 & $99 \%$ & JQ396588.1 \\
\hline $\begin{array}{l}\text { Micrococcus sp. 3498 16S } \\
\text { ribosomal RNA gene, partial } \\
\text { sequence }\end{array}$ & 2706 & 2706 & $99 \%$ & 0 & $99 \%$ & KP345957.1 \\
\hline $\begin{array}{l}\text { Micrococcus sp. 3451 16S } \\
\text { ribosomal RNA gene, partial } \\
\text { sequence }\end{array}$ & 2706 & 2706 & $99 \%$ & 0 & $99 \%$ & KP345947.1 \\
\hline $\begin{array}{l}\text { Micrococcus sp. PX9_S4 16S } \\
\text { ribosomal RNA gene, partial } \\
\text { sequence }\end{array}$ & 2704 & 2704 & $99 \%$ & 0 & $99 \%$ & JF274943.1 \\
\hline
\end{tabular}

Figure.1 Comparative growth profile of selected isolates w.r.t standard culture

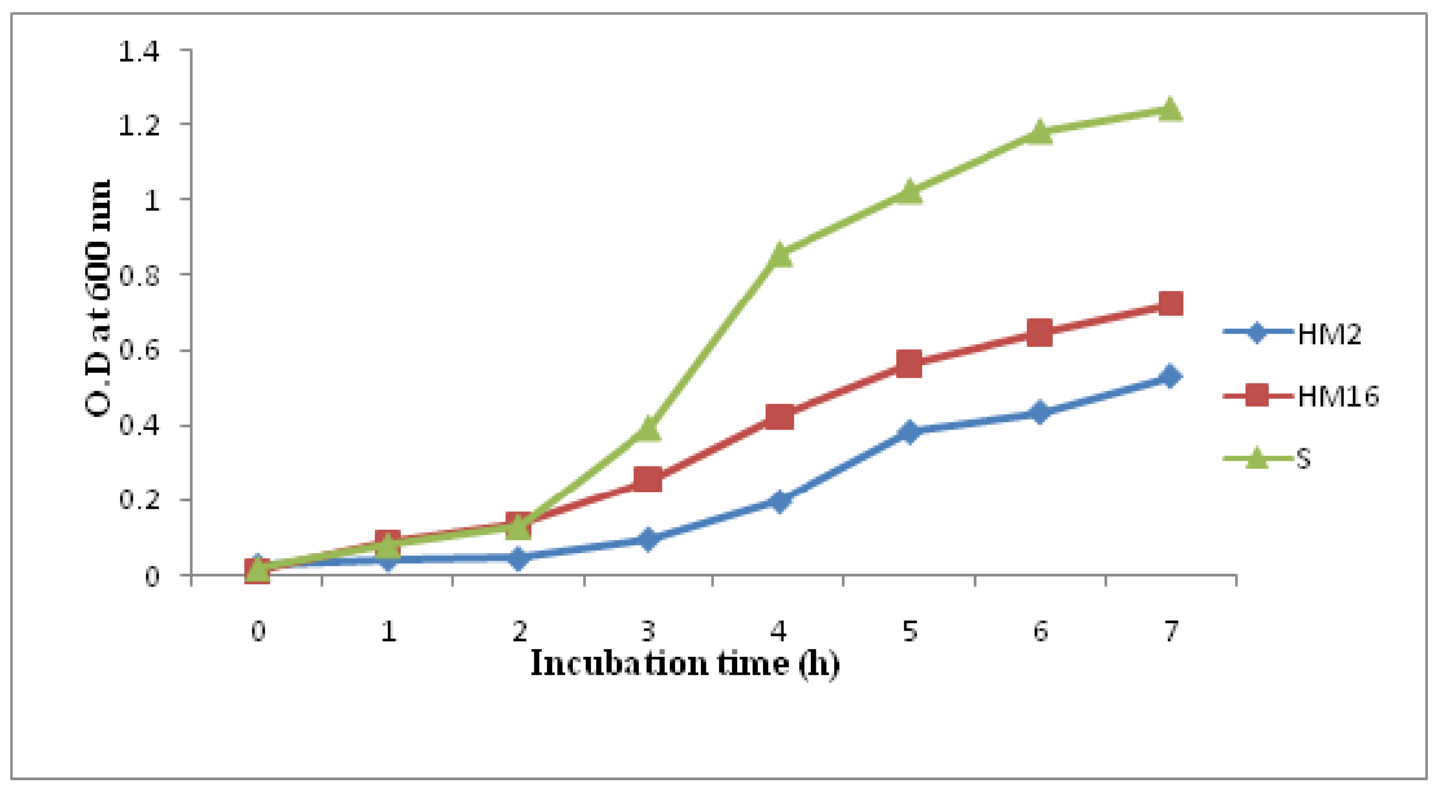


Figure.2 Comparative $\mathrm{Cr}$ reduction efficiency of selected isolates w.r.t standard culture

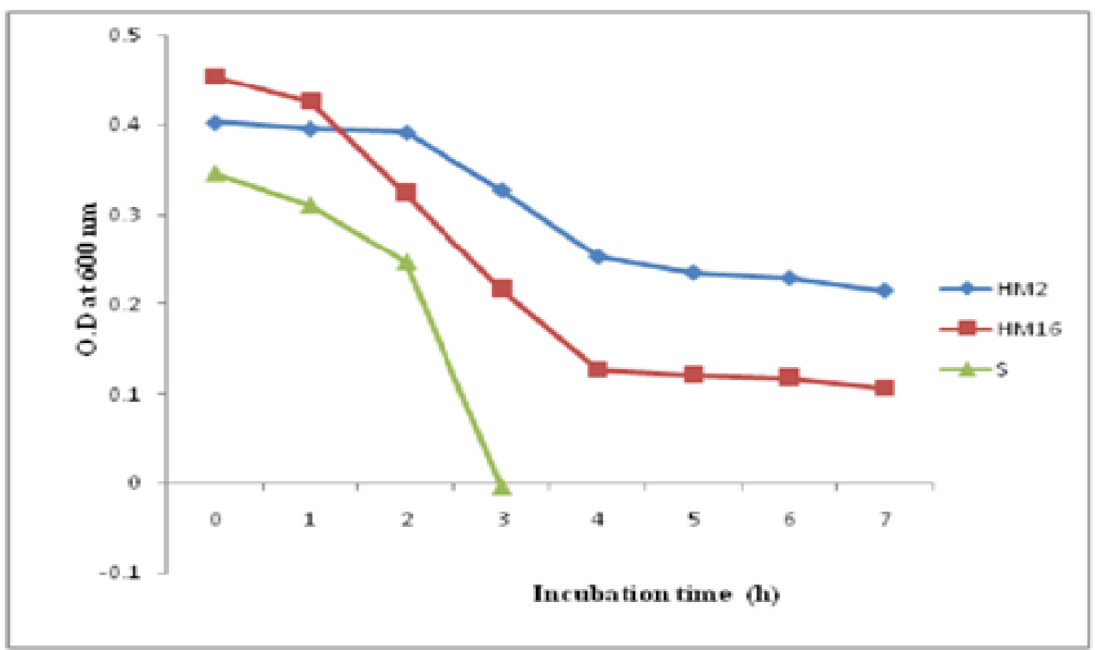

Figure.3 gDNA and 16S PCR amplicon

gDNA

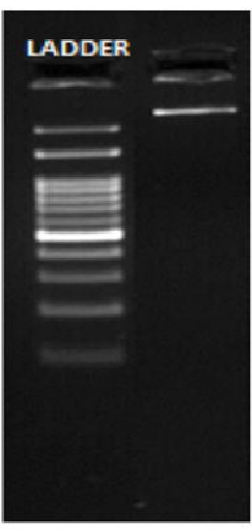

16S PCR amplicon

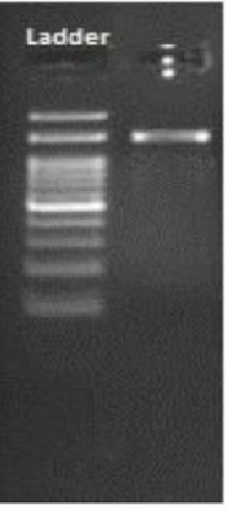

Figure.4 Molecular phylogenetic analysis by maximum likelihood method

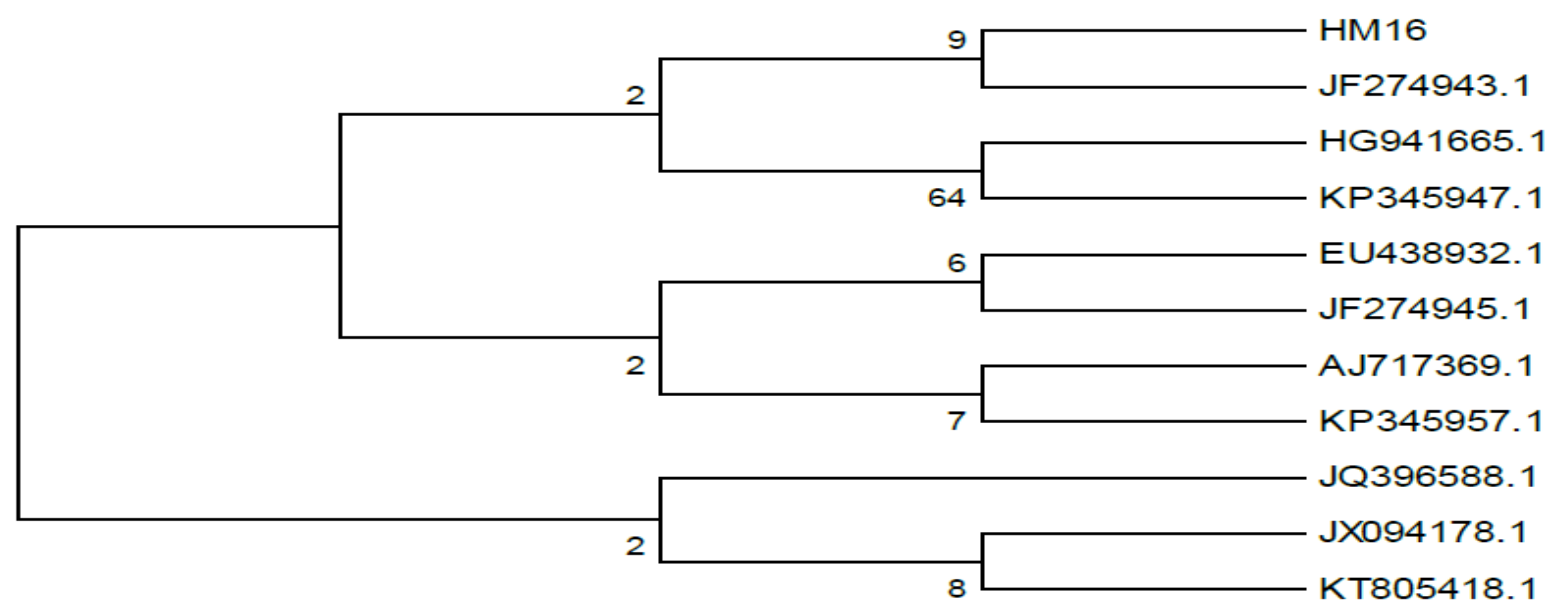


In another study, Rehman et al., (2008) found that Bacillus sp. had the ability to reduce hexavalent chromium into its trivalent form. These bacteria could reduce $91 \%$ of chromium from the medium after 96 hours and were also capable of reducing $84 \%$ chromium from the industrial effluents after 144 hours.

\section{Determination of site of Chromate reductase activity}

The chromate reductase activity of the selected isolates and standard culture was determined by DPC method. To determine the probable site of chromate reductase enzyme location, the activity was determined in cell culture supernatant, in cell lysate and in cell extract supernatant in both the isolates and standard culture. As revealed in Table 11, maximum chromate reductase activity (HM 2$0.161 \mu$ mole, HM 16- $0.163 \mu$ mole and S$0.175 \mu$ mole) were reported in cell extract supernatant in both the isolates and in standard culture. The minimum activity was reported in cell lysate.

Similarly, Ilias et al., (2011) reported the $\mathrm{Cr}$ (VI) reduction due to chromate reductase activity detected in the culture supernatant and cell lysate but not at all in cell extract supernatant of both isolates (IFR-2 and IFR3). Camargo et al., (2003) observed chromate reductase activity in the cell-free extract and soluble fraction but very low activity in the membrane fraction of Bacillus sp. ES29. Wang et al., (1990) reported that chromate reductase activity is preferentially associated in the membrane fraction of E. cloacae HO1. Batool et al., (2012) have shown the intracellular reduction of $\mathrm{Cr}$ (VI) by reductase assay using cell-free extract. Maurya and Verma (2014) also determined the concentration of $\mathrm{Cr}$ (VI) in the culture supernatant spectrophotometrically by using S-diphenyl-carbazide method.

\section{Molecular identification of the bacterial isolate by $16 \mathrm{~S}$ rDNA sequencing}

The Genomic DNA was isolated from the pure culture pellets of isolate HM 16 and $16 \mathrm{~S}$ rDNA fragment was amplified by PCR from the above isolated genomic DNA using 27F and 1492R primers. A single discrete PCR amplicon band of $1500 \mathrm{bp}$ was observed when resolved on Agarose gel. The PCR amplicon was purified by column purification in order to remove contaminants (Figure 3 ). The sequencing of purified gene segment was done using forward primer and reverse primers using BDT v3.1 Cycle sequencing kit on ABI 3730xl Genetic Analyzer. The 16S rDNA gene sequence was used to carry out BLAST with the database of NCBI genbank database. Based on maximum identity score first ten sequences were selected and aligned using multiple alignment software program Clustal W. Sequencing and analysis of the $16 \mathrm{~S}$ rDNA region of the isolated bacterial strain HM 16 revealed that these regions had the highest identity with Microccocus luteus. Phylogenetic relationships were inferred through the alignment and cladistic analysis of homologous nucleotide sequences of known microorganisms (Table 12). The evolutionary history was inferred by using the Maximum Likelihood method based on the Kimura 2-parameter model (Kimura 1980). The bootstrap consensus tree inferred from 1000 replicates is taken to represent the evolutionary history of the taxa analyzed (Felsenstein, 1985). Branches corresponding to partitions reproduced in less than $50 \%$ bootstrap replicates are collapsed. The percentage of replicate trees in which the associated taxa clustered together in the bootstrap test (1000 replicates) are shown next to the branches (Felsenstein, 1985). The phylogenetic tree was depicted showing the relationship of this isolate with the genus Micrococcus (Figure 4). In this study, results revealed that sample which was labelled as 
HM 16 showed high similarity with Micrococcus luteus based on nucleotide homology and phylogenetic analysis. Similarly, Pattanapipitpaisal, Brown and Macaskie (2001) isolated chromium tolerant bacterium from tannery effluent and was identified as a Microbacterium sp. by $16 \mathrm{~S}$ rDNA gene sequence homology. Chromium reduction has been reported in several bacterial strains. An indigenous chromium reducing bacterial strain isolated from a tannery water sample, was identified as Ochrobactrum intermedium, on the basis of 16S rDNA gene sequencing (Batool et al., 2012). Balamurugan et al., 2014 isolated two strains (CTBI 1 and CTBI 2) having chromium reduction capacity and showed a sequence homology of $95.68 \%$ with Pseudomonas putida and $95.19 \%$ with Bacillus subtilis.

In conclusion, the present study revealed the capacity of the bacterial isolates HM 2 and HM 16 (Micrococcus luteus), isolated from effluent samples, to tolerate and grow at different concentrations of $\mathrm{Cr}$ (VI) with $\mathrm{Cr}$ (VI) reduction ability. The isolates were able to resist upto $100 \mathrm{ppm}$ of chromium. To determine the ability of selected isolates to show reduction of $\mathrm{Cr}$ (VI) to $\mathrm{Cr}$ (III), both the isolates were tested for enzyme chromate reductase and compared with a standard strain Shewanella putrefaciens. Whereby, 99\% reduction of $\mathrm{Cr}$ (VI) by the standard culture followed by $76.66 \%$ reduction by HM 16 and $46.76 \%$ reduction by HM 2 within 7 hours of incubation was observed. Molecular characterization of HM 16 showed high similarity with Micrococcus luteus based on nucleotide homology and phylogenetic analysis. This study elucidated the potential of resident microbes of effluents/sludge for heavy metal mainly chromium removal, as these bacterial species were well acclimatized to the ecology of metal contaminated aquifers.

\section{Acknowledgement}

The authors acknowledge the help and support rendered by operation head and staff of Common Effluent Treatment plants located in Ludhiana and Jalandhar.

\section{Conflict of Interest}

The authors state that there are no conflicts of interest regarding the publication of this article.

\section{References}

Alam, M. Z., Ahmad, S. and Malik, A. 2011. Prevalence of heavy metal resistance in bacteria isolated from tannery effluents and affected soil. Environ. Monit. Assess. 178:81-91.

APHA, 2001. Standard methods for the examination of water and waste water. $20^{\text {th }}$ edition. Washington D.C: American Public Health Association.

Balamurugan, D., Udayasooriyan, C. and Kamaladevi, B. 2014. Chromium Cr (VI) reduction by Pseudomonas putida and Bacillus subtilis isolated from contaminated soils. Int. J. Environ. Sci. 5(3): 522-29.

Bartlett, R.J. and James, B.R. 1996. Chromium. In: Methods of soil analysis. Sparks D L (ed) Part 3, SSSA Book Series 5. Pp 683-701. SSSA, Madison.

Basu, M., Bhattacharya, S. and Paul, A.K. 1997. Isolation and characterization of chromium-resistant bacteria from tannery effluents. Bull. Environ. Contam. Toxicol. 58:535-42.

Batool, R., Yrjala, K. and Hasnain, K. 2012. Hexavalent chromium reduction by bacteria from tannery effluent. $J$. Microbiol. Biotecnol. 22(4):547-54.

Boyd, R.S. 2010. Heavy metal pollutants and chemical ecology: Exploring new 
frontiers. J. Chem. Ecol. 36:46-58.

Camargo, F.A.O, Okeke, B.C., Bento, F.M. and Frankenberger, W.T. 2003. In vitro reduction of hexavalent chromate-reducing Pseudomonas aeruginosa $\mathrm{A} 2 \mathrm{Chr}$ in two bioreactors. Appl. Microbiol. Biotechnol. 58:41620.

Cheung, K.H. and Gu, J.D. 2003. Reduction of chromate $\left(\mathrm{CrO}_{4}{ }^{2-}\right)$ by an enrichment consortium and an isolate of marine sulphate-reducing bacteria. Chemosphere 52:1523-29.

Congeevaram, S., Dhanarani, S., Park, J., Dexilin, M. and Thamaraiselvi, K. 2007. Biosorption of chromium and nickel by heavy metal resistant fungal and bacterial isolates. J. Hazard. Mater. 146:270-277.

Debabrata, B., Parimal, C. and Lalitagauri, R. 2006. Chromium (VI) biosorption by immobilized biomass of Bacillus cereus M1. J. Hazard. Subs. Res. 6:123.

Dermou, E., Velissariou, A., Xenos, D. and Vayenas, D.V. 2005. Biological chromium (VI) reduction using a trickling filter. J. Hazard. Mater. 26:78-85.

Directive 98/83/EC, 2003. Drinking water quality intended for human consumptions. EPA, USA.

Dixit, R., Wasiullah, W., Malaviya, D., Pandiyan, K., Singh, U.B., Sahu, A., Shukla, R., Singh, B.P., Rai, J.P., Sharma, P.K., Lade, H. and Paul, D. 2015. Bioremediation of heavy metals from soil and aquatic environment: An overview of principles and criteria of fundamental processes. Sustainability 7:2189-2212.

Dmitrenko, G.N., Konovalova, V.V. and Shum, O.A. 2003. The reduction of $\mathrm{Cr}$ (VI) by bacteria of the genus Pseudomonas. Microbiol 72:327-30.

Elangovan, R., Abhipsa, S., Rohit, B., Ligy,
P. and Chandraraj, K. 2006. Reduction of Cr (VI) by a Bacillus sp. Biotechnol Lett. 28:247-52.

Felsenstein, J. 1985. Confidence limits on phylogenies: An approach using the bootstrap. Evol. 39:783-91.

Flavio, A.O., Camargo, C., Benedict, O., Fatima, M., Bento, W. and Frankenberger, T. 2004. Diversity of chromium-resistant bacteria isolated from soils contaminated with dichromate. Appl. Soil Ecol. 29:193202.

Francisco, R., Alpoim, M.C. and Morais, P.V. 2002. Diversity in chromium-resistant and reducing bacteria in a chromiumcontaminated activated sludge. $J$. Appl. Microbiol. 92:837-43.

Gunaseelan, C. and Ruban, P. 2011. Heavy metal resistance bacterium isolated from Krishna Godavari basin, Bay of Bengal. Int. J. Environ. Sci. 1:185664.

Hashim, M., Mukhopadhyay, S., Sahu, J.N. and Sengupta, B. 2011. Remediation technologies for heavy metal contaminated groundwater. $J$. Environ. Manage. 92:2355-88.

Ilias, M., Rafiqullah, Md. I., Debnath, B.C., Mannan, K.S.B. and Hoq Mozammel, Md. 2011. Isolation and characterization of chromium (VI)reducing bacteria from tannery effluents. Indian. J. Microbiol. 51:7681.

Katyal, P., Sahota, P.P., Singh, D. and Sikka, R. 2015. Prevalence of heavy metal resistant bacteria in samples from sewage treatment plants and common effluent treatment plants. J. Env. Biosci. 29(2):533-38.

Kimura, M. 1980. A simple method for estimating evolutionary rate of base substitutions through comparative studies of nucleotide sequences. $J$. Mol. Evol. 16:111-20. 
Klaus-Joerger, T., Joerger, R., Olsson, E. and Granqvist, C. 2001. Bacteria as workers in the living factory: metalaccumulating bacteria and their potential for materials science. Trends. Biotechnol. 19:15-20.

Kumar, S., Stecher, G. and Tamura, K. 2016. MEGA7: Molecular Evolutionary Genetics Analysis version 7.0 for bigger datasets. Mol. Biol. Evol. 33(7):1870-74.

Liu, J., Wang, J., Qi, J., Li, X., Chen, Y., Wang, C. and Wu, Y. 2012. Heavy metal contamination in arable soils and vegetables around a sulfuric acid factory, China. Clean. Soil. Air. Water. 40(7):766-72.

Lu, Y.L. and Yang, J.L. 1995. Long-term exposure to chromium (VI) oxide leads to defects in sulfate transport system in Chinese hamster ovary cells. J. Cell. Biochem. 57:655-65.

Marsh, T. L. and McInerney, M.J. 2001. Relationship of hydrogen bioavailability to chromate reduction in aquifer sediments. Appl. Environ. Microbiol. 67:1517-21.

Maurya, A. and Verma, T. 2014. Concomitant bioremediation of chromium (VI) and pentachlorophenol from the tannery effluent by immobilized Brevibacterium casei. IOSR J. Eng. 11:29-39.

Mclean, J. and Beveridge, T.J. 2001. Chromate reduction by a Pseudomonad isolated from a site contaminated with chromated copper arsenate. Appl. Environ. Microbiol. 67:1076-84.

Ohtake, H. and Silver, S. 1994. In: Chaudhry G R (Ed.) Biological degradation and bioremediation of toxic chemicals. Dioscorides Press, Portland, Oregon, pp. 403-15.

Oladipo, O.G., Olayinka, A. and Awotoye, O.O. 2014. Ecological impact of mining on soils of Southwestern Nigeria. Environ. Exp. Biol. 12:179186.

Pal, A., Dutta, S. and Paul, A.K. 2005. Reduction of hexavalent chromium by cell-free extract of Bacillus sphaericus 303 isolated from serpentine soil. Curr. Microbiol. 51:327-30.

Pandit, R.J., Patel, B., Kumjadia, P.D. and Nagee, A. 2013. Isolation, characterization and molecular identification of heavy metal resistant bacteria from industrial effluents, Amala-Khadi-Ankleshwar, Gujarat. Int. J. Environ. Sci. 3(5):1689-99.

Pattanapipitpaisal, P., Brown, N.L. and Macaskie, L.E. 2001. Chromate reduction and $16 \mathrm{~S}$ rRNA identification of bacteria isolated from a $\mathrm{Cr}$ (VI)contaminated site. Appl. Microbiol. Biotechnol. 57:257-61.

Rehman, A., Zahoor, A., Muneer, B. and Hasnain 2008. Chromium tolerance and reduction potential a resistance in the cyanobacterium Nostoc calcicola. FEMS. Microbiol. Lett. 84:291-94.

Shah, M.T., Ara, J., Muhammad, S., Khan, S., Asad, S.A. and Ali, L. 2014. Potential heavy metals accumulation of indigenous plant species along the mafic and ultramafic, Terrain in the MoCTand Agency, Pakistan. Clean. Soil. Air. Water. 42(3):339-46.

Singh, A. and Prasad. S. 2015. Remediation of heavy metal contaminated ecosystem: An overview on technology advancement. Int. J. Environ. Sci. Technol. 12:353-66.

Singh, H., Singh, P. and Singh, D. 2015. Chemical fractionation of heavy metals and nutrients in sludge and waste water generated by coca-cola soft drink industry. Archives of Agronomy and Soil Science 61(1):11938.

Singh, N., Verma, T. and Gaur, R. 2013. 
Detoxification of hexavalent chromium by an indigenous facultative anaerobic Bacillus cereus strain isolated from tannery effluent. African. J. Biotechnol. 12:1091:1103.

Sisti, F., Allegretti, P. and Donati, E. 1996. Reduction of dichromate by Thiobacillus ferroxidans. Biotechnol. Lett. 18:1477-80.

Srinath, T., Verma, T., Ramteke, P.W. and Garg, S.K. 2002. Chromium (VI) biososrption and bioaccumulation by chromate resistant bacteria. Chemosphere. 48:427-35.

Srivastava, H., Mathur, R. and Mehrotra, I. 1986. Removal of chromium from industrial effluent by absorption on sawdust. Environ. Technol. Lett. 7:5563.

Thacker, U. and Madamwar, D. 2005. Reduction of toxic chromium and partial localization of chromium reductase activity in bacterial isolate DM1. World. J. Microbiol. Biotechnol. 21:891-99.

Thompson, M. and Walsh, J.N. 1989. Handbook of inductively coupled plasma spectrometry. Blackie. ISBN 02169226X, 9780216922648.

Verma, T., Srinath, T., Gadpayle, R.U.,
Ramteke, P.W., Hans, R.K. and Garg, S.K. 2001. Chromate tolerant bacteria isolated from tannery effluent. Biores. Technol. 78:31-35.

Vijayananda, S. and Hemapriya, J. 2014. Biosorption and detoxification of $\mathrm{Cr}$ (VI) by tannery effluent acclimatized halotolerant bacterial strain $\mathrm{pv}_{26}$. Int. J. Curr. Microbiol. Appl. Sci. 3:971-82.

Wang, P.C., Mori, T., Toda, K. and Ohtake, H. 1990. Membrane associated chromate reductase activity from Enterobacter cloacae. J. Bacteriol. 172:1670-72.

Wang, P.C., Mori, T., Komori, K., Sasatsu, M., Toda, K. and Ohtake, H. 1989. Isolation and characterization of an Enterobacter cloacae strain that reduces hexavalent chromium under anaerobic conditions. Appl. Environ. Microbiol. 55:1665-69.

Wang, Y.T. and Xiao, C. 1995. Factors affecting hexavalent chromium reduction in pure cultures of bacteria. Water Res. 29:2467-74.

Yao, Z., Li, J., Xie, H. and Yu, C. 2012. Review on remediation technologies of soil contaminated by heavy metals. Proc. Environ. Sci. 16:722-29.

\section{How to cite this article:}

Katyal, P. and Kaur, G. 2018. Reduction of Cr (VI) by Micrococcus luteus isolate from Common Effluent Treatment Plants (CETPs). Int.J.Curr.Microbiol.App.Sci. 7(07): 693-710. doi: https://doi.org/10.20546/ijcmas.2018.707.084 